\title{
The Effectiveness of E-Recruitment Method Through Social Media (Case Study at Pt Es Teh Tndonesia Makmur - West Java)
}

\author{
Jazimatul Husna ${ }^{1}$, Salsabila Sadiqin ${ }^{2}$, Yahya Muhaimin ${ }^{3}$, Fitriyana ${ }^{4}$, Roisatul Wahdiyah ${ }^{5}$ \\ ${ }^{1}$ Lecturers of Information and Public Relations, Vocational School, Diponegoro University, Indonesia \\ ${ }^{2}$ Students of Information and Public Relations, Vocational School, Diponegoro University, Indonesia \\ ${ }^{3}$ Students of Information and Public Relations, Vocational School, Diponegoro University, Indonesia \\ ${ }^{4}$ Students of Library science, Faculty of Humanities, Diponegoro University, Indonesia \\ ${ }^{5}$ Teacher of English as a Second Language, Madrasah Aliyah AS Risalatul Huda Sofifi At Maluku, \\ Indonesia MA At Maluku, Indonesia
}

\begin{abstract}
Several companies have reduced mass recovery efforts and inperson discussions for the Covid-19 pandemic password, one of which is PT Es Teh Indonesia Makmur. This study aims to: (1) Know the media for posting jobs and the application of the recruitment process through social media, including the stages and qualifications and competencies required at PT Es Teh Indonesia Makmur (2) Knowing the effectiveness of recruitment methods through social media to reduce the impact of the Covid-19 pandemic era and explains the comparison of the E-Recruitment method with the offline recruitment method at PT Es Teh Indonesia Makmur. The effectiveness of the Recruitment Method through social media by studying library data and observations shows that the electronic recruitment system for the workforce is suitable to be used to facilitate and improve human resource management in the Covid-19 Pandemic era. An increase in competent job applicants supports this, and PT Es Teh Indonesia Makmur is known to all circles to open job vacancies for more than 150 outlets in less than one year.
\end{abstract}

\section{Introduction}

In running a company or an organization, leaders and employees are needed. Employees are one of the human resources (HR) assets that a company or organization must own. Creating a company or organization that is constantly growing takes an employee who is capable and skilled in their field. A good management pattern is also needed to mobilize and manage human resources to grow better, more effectively, and efficiently by the real needs of the company and organization. The importance of human resource management or employees, according to Dharmawan Soedaryono [2] that an employee is someone who works for a company or organization, both in government and private work units, to support his life. In running a company or an organization, implementing human resource management (HR), several essential activities must be designed and practised. These activities consist of planning, recruitment, direction, development, maintenance, and dismissal of human 
resources. This activity is carried out in order to maximize the management of human resources effectively and efficiently.

Foulkes (1975) predicts that the role of HR over time will become more strategic, and Foulkes said: "For many years it has been said that capital is the bottleneck for a developing industry. I don't think this any longer holds. I think it's the workforce and the company's inability to recruit and maintain a good workforce that does constitute the bottleneck for production. .... I think this will hold even more in the future". From Foulkes' statement, it is not surprising that now for reliable HR management, we use the terminology of human capital, which we hear more and more, this causes leaders to associate HR implementation with organizational strategies to improve performance, develop a corporate culture that supports the implementation of innovation and company flexibility and organization.

In practice, the first important thing that must be done in HR management is to carry out a recruitment or withdrawal process. A company carries out this activity to obtain the best human resources according to the qualifications required by the company with existing positions. The withdrawal process, according to Kukuh Hasibuan [7] states that recruitment process is an attempt to find and influence workers to apply for job vacancies in a company or organization. This process is essential and plays a very important role in managing competent and skilled human resources in their fields. An effective withdrawal process will bring opportunities for people whose abilities and skills meet specifications in a company's growth.

Furthermore, Dharmawan Hanafi and Aminullah [2] argue that one of the goals of recruitment is that a company provides sufficient employees. It is selected, and the leadership can choose prospective employees who meet the criteria and qualifications they consider is needed. After carrying out the withdrawal or recruitment process, prospective employees who are declared to have passed and meet the expected criteria and qualifications can work and complete tasks and jobs as efficiently as possible to achieve the company's goals. Of course, this process must be carried out in the right way to get quality human resources to determine the company's success in the long term.

Life will not return to normal in the next few months and recover like it was before the Covid-19 pandemic. Meanwhile, the business world cannot wait until the corona vaccine is found and must adapt to a new normal life by implementing new methods in many ways, including employee recruitment strategies. Companies are starting to adopt a system that is no longer at risk of spreading the virus; digital technology inevitably becomes the company's backbone in the process of finding the best talent. Along with the development of technology in this digital era which is increasingly sophisticated and the internet is growing rapidly. Many things are now using the internet media, and this also applies to competition between companies in developing Human Resources for these companies.

The Covid-19 pandemic has triggered long-term changes in the recruitment process for each company that has been heavily involved in recruiting potential candidates from different sources to date, the organization's old recruitment strategy will not work, and demands companies to reinvent and put in place new recruitment strategies that are not successful. Relevant to the times and can be applied efficiently.

Considering the impact of the Covid-19 pandemic on the workforce, of course, the role of social media does not stop in recruiting employees but also has a role in helping people get new jobs and keeping individuals involved after being recruited. One of them is a recruitment method through social media or what is called E-Recruitment. E-Recruitment is a new staffing recruitment system both internally and externally for any business firm interested in recruiting active employees by finding their greater presence via social media. The social posting provides an online solution that covers an end-to-end hiring process, from requirements for recruiting to the successful appointment of candidates. 
As a result of Covid-19, many large companies in Indonesia are currently starting to implement online withdrawal patterns and practices through social media, or so-called eRecruitment. One of them has been done by PT Es Teh Indonesia. PT Es Teh Indonesia is a tea beverage business company that was built and developed by several young entrepreneurs who have a vision of "To become the Largest Tea Drink Company in Indonesia, Asia, and the World". Haidhar Wurjanto is one of the figures behind PT Es Teh Indonesia. The CEO of PT Es Teh Indonesia explained that the ice tea business in Indonesia is currently growing and spreading in many Indonesian cities, including Medan, Palu, Makassar, and also various cities on the island of Java.

PT Es Teh Indonesia has created the widest possible job opportunities through social media which are now widely used by the millennial generation. Withdrawal or recruitment through social media or e-Recruitment makes researchers interested in examining the patterns, practices, and stages applied in the recruitment of PT Es Teh Indonesia Makmur employees through social media.

Based on the explanation above, this research takes the title "The Effectiveness of Recruitment Methods through Social Media (e-Recruitment) (A Case Study at PT Es Teh Indonesia - West Java) [11]. In this study, the purpose of this research is to find out how the e-recruitment process for new employee candidates is applied to PT Es Teh Indonesia. The focus of this research is related to the effectiveness of recruitment through social media (eRecruitment) at PT Es Teh Indonesia. The results of this study are expected to provide an overview of the implementation of the online recruitment process (e-Recruitment) and provide results in the form of higher quality human resources who can grow in a more effective and efficient management process.

\section{Method}

This research uses a literature study approach and descriptive analysis method. The method used is the literature study approach because this approach is considered to measure how much the effectiveness of the e-recruitment method through social media by collecting, reading, and taking notes, and processing research materials. This study also uses descriptive analysis to take a problem or decide attention to problems when the research was carried out. The results of the research were then processed and analyzed to conclude.

\subsection{Research Focus}

\subsubsection{The focus of recruitment research through social media includes:}

The type of social media used as a means of job hiring and job posting of e-Recruitment and the stage that is carried out in online recruitment.

\subsubsection{The focus of research on effective recruitment through social media includes:}

The suitability of the prospective job applicant with what is expected and comparing online recruitment methods with offline recruitment. 


\subsection{Research Data Collections Technicues}

\subsubsection{Study of Literature}

This technique is also called literature study, a way of tracing decisions that contain theories from published or unpublished scientific works in the form of hard or soft copies in books (e-books), papers, online journals. This literary technique is used as a primary data collection technique in testing whether or not the research results obtained about the effectiveness of recruitment through social media in the context of adapting to the current Covid-19. The importance of literature studies is because the data are permanent, authentic, easy to find, and can be justified because the literature data has validity and has gone through standard research procedures. Literature study, as a technique in research to obtain data, is used because the data obtained is in the form of theories that support research activities; The data obtained will be used to verify the quality of the theory found from the research results; Authentic data from literature studies can be justified. This literature study technique is sourced from books, research reports, scientific journals, and other notes, trying to find relevant theoretical sources according to the predetermined themes and research problems so that the resulting research is as expected.

\subsubsection{Observation}

Observation is a data collection technique carried out through observation, accompanied by notes on the state or behaviour of the target object. The purpose of observation is to describe the activities, a process, the people involved in the activity, the time of the activity, and the relevant meanings to be used as research material. Based on the involvement of the observer in the activities of the observed person, observation can be divided into participant observation and non-participant observation. In this study, researchers used non-participant observation techniques in which the observer only performed one function, namely making observations. The non-participant observation technique was used because, in this research process, the researcher did not participate in the field but only played a role in observing through the official website, Instagram, TikTok, Twitter, and Facebook-owned by PT Es Teh Indonesia Makmur by collecting valid data to support and support the opinion. Regarding erecruitment methods, comparisons with other methods, and the effectiveness of recruitment through social media at PT Es Teh Indonesia Makmur.

\section{Results and Discussion}

\subsection{Stages of Recruitment through Social Media}

\subsubsection{The type of social media used as a means of job hiring and job posting of e- recruitment}

The means of job hiring and posting of e-Recruitment Online used by PT Es Teh Indonesia Makmur are electronic media. The electronic media, especially the social media used by PT Es Teh Indonesia, are mainly Instagram, Facebook, Twitter, and TikTok. PT Es Teh Indonesia Makmur also has an official website, namely estehindonesia.com. PT Es Teh Indonesia Makmur also uses social media celebrity endorsements, commonly known as celebrities, and other Indonesian celebrities. This is also closely related because one of the owners of PT Es Teh Indonesia Makmur is a young singer named Brissia Jodie. 


\subsubsection{The stages carried out in online recruitment}

The company's fundamental thing in carrying out the online recruitment process of prospective employees to fill the positions needed by the company can be a crucial and very challenging stage for the company. A guideline is needed in building human resources that could grow in accordance with the wishes of the company. For example, minimizing the number of prospective employees who will be accepted does not actually meet the qualifications and skill requirements desired by the company. In order to find the desired workers, nowadays, many companies make processes that are efficient, accurate, easy, and convenient. One of the recruiting systems developed uses information technology and other internet technology support, for example, by utilizing social media to implement these processes.

The opening of job vacancies and recruitment of prospective workers through TikTok conducted by PT Es Teh Indonesia Makmur is specifically for staff trainers, opening store staff, quality control staff, marketing supervisors, and the Tehtok division. Tehtok is a marketing and advertising division owned by PT Es Teh Indonesia. This division will have a job desk as an appraiser for prospective employees. One of the job desks of this division is to make creative videos which will later be uploaded via Tiktok. Through social media owned by PT Es Teh Indonesia Makmur, some of the main requirements to become a part of PT Es Teh Indonesia Makmur are explained, namely: Male / female aged 19 to 25 years; Graduates of SMK / SMA and equivalent; Have an honest attitude, be responsible, and be able to work together in a team; Physically and mentally healthy; Willing to work shift (full time); Single; Domicile by the garden (shop) that opens vacancies.

The opening of job vacancies by PT Es Teh Indonesia Makmur is through the Tiktok platform and from other platforms, one of which is Instagram. On the official Instagram, PT Es Teh Indonesia Makmur explained several new job vacancies, namely graphic designer, finance manager, logistics driver, and crew. Of course, the recruitment stages through the Instagram platform are a little different compared to TikTok. Opening job vacancies via Instagram is called a bit formal because applying requires several particular files sent directly to the place where the prospective worker registers. There are special requirements given to prospective applicants who will apply as graphic designers and finance managers. In graphic designers, some of the requirements are as follows: Male/female max 30 years old; Minimum education D3 DKV / Communication / Advertising/equivalent; Experience in the creative industry or F\&B min. 1 year (fresh graduate are welcome); Have a unique taste of design / out of the box and up to date trends on social media and F\&B trends; Know the basic science of marketing and branding; Proficient in Ai, Ps software (Pr and Ae or similar software for video and motion editing is a plus); Good command of Microsoft word, excel, and PowerPoint software; Willing to be placed at the Indonesian Ice Tea Headquarters in Bogor City.

There are some special requirements beyond the main requirements in the finance manager itself, namely a minimum educational background of S1 Accounting/equivalent and having experience as a finance manager for at least 2 years. In the logistics driver, there are also some special requirements outside of the main requirements, including male, maximum age 40 years, and has a SIM A or B. In addition, for workers as plantation crew of PT Es Teh Indonesia, there are special requirements including male / female aged 19 to 25 years and preferably experienced as a tender or barista.

The opening of job vacancies by PT Es Teh Indonesia Makmur through Tiktok received many positive responses from the audience. The analysis carried out shows that this is due to the impact of the Covid-19 pandemic, which caused many employees to be fired. PT Es Teh Indonesia Makmur took this opportunity to find suitable workers differently from before. PT Es Teh Indonesia Makmur makes job advertisements via TikTok. According to cellular.id, 
Tiktok users in Indonesia have reached 30.7 million users. This is a golden opportunity for new companies whose target market is the millennial generation.

From the results of an interview conducted by Madiunpos with Haidhar as the founder of PT Es Teh Indonesia Makmur, he explained that recruitment through TikTok is not difficult. First, PT Es Teh Indonesia Makmur opens job vacancies or what is commonly known as open recruitment. This open recruitment is conveyed through an innovative video made by one of the founders of PT Es Teh Indonesia Makmur, Haidhar Wurjayanto, through a platform currently favoured by many, namely Tiktok. This video has been watched by more than 3.2 million views. The many platforms used by PT Es Teh Indonesia Makmur make applicants even more incessant to apply. Some of the platforms used include Instagram, Facebook, and the most visited is TikTok. Of the several applications used for product advertisement delivery media and open recruitment, TikTok is the most influential. The video posted by Haidhar has a tremendous impact on the company, increasing turnover to opening new branches. The opening of this new branch makes PT Es Teh Indonesia Makmur need workers who can adapt to technological developments. The opening of job vacancies through this Tiktok, the workers will be explicitly assigned to the Tehtok division.

The next stage is making creative videos by prospective workers. This video contains a short profile or short cv. This 1-minute video must be posted using a special hashtag and tagging the TikTok Estehindonesia and its founder accounts to make it easier to assess. At this publishing stage, Haidhar did not specifically mention what criteria were needed, but he judged that from the most interesting and creative videos according to PT Es Teh Indonesia Makmur.

The third stage is the assessment stage. After publishing the video, PT Es Teh Indonesia Makmur, the Tehtok division, will judge it according to the suitability criteria such as the applicant's profile, the completeness of the profile, and the uniqueness and attractiveness of the video.

Next, the announcement of passing the creative video stage selection via TikTok; this announcement is made by contacting the selected applicants directly. Furthermore, the applicant will be asked to come to the office where he is applying for an interview by bringing some files such as CV, Application Letter, Photocopy (KTP, Last Diploma, Value Transcript, KK, Latest Color Photo 4x6).

Fifth, interview selection is carried out at branch and central offices depending on where the applicant applies. For example, its mission is to improve the quality of Human Resources (HR), questions about experiences, and some specific questions that are kept secret. This selection is not determined and pegged how much will be accepted. Several founders of PT Es Teh Indonesia Makmur explained in the video uploaded via TikTok that they wanted to create vast employment opportunities for applicants affected by the Covid-19 pandemic.

The final stage is to make a final agreement between PT Es Teh Indonesia Makmur and the applicant. After going through several series of selections, PT Es Teh Indonesia Makmur announces whether the applicant is eligible to be placed and collaborates with PT Es Teh Indonesia Makmur or not. The next step is if it has been accepted, the explanation regarding the work contract. At the end of this stage, workers who are ready to work will be immediately hired.

\subsection{Effectiveness of recruitment through social media}

In the video uploaded by one of the founders of PT Es Teh Indonesia Makmur, Haidhar explains several leading indicators that can measure whether a prospective worker is worthy of being part of PT Es Teh Indonesia Makmur. Some of these indicators are the creativity possessed by prospective workers, the attractiveness of the candidate's video, experience, and 
the uniqueness of the video made by the candidate. However, this is also supported by the official documents owned by prospective workers.

Siagian explained that "Effectiveness is the use of resources, facilities, and infrastructure in a certain amount which is consciously determined in advance to produce some goods for the services of the activities it carries out." Effectiveness shows success in terms of whether the targets have been achieved or not. If the results of the activity are closer to the target, it means that the effectiveness will be higher" (Siagian, 2010: 4).

\subsubsection{Compatibility of prospective job applicants with expected}

Based on the observations and the results of interviews conducted by researchers related to the Tehtok division, it can be explained that PT Es Teh Indonesia is implementing the online ordering method (E-Recruitment) starting in 2020. Before the application of the eRecruitment method, PT Es Teh Indonesia had a few applicants. After the e-Recruitment process is carried out, the number of applicants and prospective employees who enter have met the targets set by PT Es Teh Indonesia. As described by Galanaki (2002), this method also states that the recruitment method through social media is effective in terms of the reach of the labour market. He surveyed a sample of 99 organizations, of which 34 responded. From several previous studies and those conducted by researchers, applying the recruitment method through social media (e-recruitment) at PT Es Teh Indonesia Makmur has provided many advantages, one of which is the broader reach of applicants and prospective applicants employees. Furthermore, Phoraris (2016) ode of withdrawal or recruitment with the benefits of social media (e-Recruitment) has provided a big advantage in the form of a Bigger audience, with the help of the internet, which is not limited by regional boundaries. Everyone can access e-Recruitment, so who can access this job is greater. It can be concluded that the recruitment method through social media in terms of the target applied at PT Es Teh Indonesia Makmur is very effective.

\subsubsection{Comparing online recruitments method with other recruitments}

The use of online recruitment methods through social media is considered adequate for several reasons. First, this method makes use of existing social media. The fact is that many social media users are the main thing to consider when opening jobs through social media. Currently, social media users are millennials and almost from all walks of life and are vulnerable to age. According to cellular.id, Tiktok users in Indonesia have reached 30.7 million users. Not to mention other social media users such as Instagram, Facebook, and Twitter.

Second, this method has a greater reach than using only print media. Social media itself has been able to be accessed by all people in all countries. This is, of course, the primary factor why this method is considered more effective.

Third, this method saves much time in distributing advertisements or disseminating information regarding job openings. You just need a fast connection and go through a fast process. The company is also sufficient for publishing and advertising features to make the uploads spread throughout the country.

In terms of electronic media used by PT Es Teh Indonesia Makmur, online and electronic media are used, namely social media in Facebook, Tiktok, Twitter, and official Instagram from PT Es Teh Indonesia Makmur to be addressed to general and fresh graduates applicants. Moreover, offline distribution such as poster printing is not used because it is less effective due to the time duration and difficulty in understanding the listed qualifications. Meanwhile, PT Es Teh Indonesia Makmur took advantage of this pandemic situation to produce very creative ideas in recruiting new workers using TikTok social media. This idea has resulted in 
many positive responses from the audience and the number of job applicants at PT Es Teh Indonesia. Prosperity has greatly increased.

From this, PT Es Teh Indonesia Makmur can open more job opportunities for job applicants. At this time, PT Es Teh Indonesia Makmur has been able to open new branches (gardens) up to 150 branches (gardens) in various areas of the city so that the effectiveness of recruitment through TikTok's social media can result in increased sales and significantly increased attractiveness for job applicants compared to other recruitment methods.

\section{Conclusion}

The application of the recruitment process through social media (E-Recruitment) in the recruitment of workers at PT Es Teh Indonesia Makmur from the early stages of open recruitment through the official TikTok account until making the final agreement has gone well and is in accordance with the theoretical basis. The job posting facilities used are online media in social media, TikTok, Instagram, Twitter, and official Facebook belonging to PT ES Teh Indonesia Makmur.

The effectiveness of the recruitment method through social media from the target aspect has been proven to increase the number of applicants. This is evidenced by the number of job applicants who exceed the initial target at PT Es Teh Indonesia. The recruitment method through social media has produced significant results; it is proven that PT Es Teh Indonesia Makmur can open up more job opportunities for job seekers.

\section{References}

1. Arnomo, Ilham. Efektivitas Proses Rekrutmen dan Seleksi Karyawan Menggunakan Sistem Online. Jurnal Humaniora, Kopertis Wilayah VII, Surabaya Volume 13, Nomor 2, Desember (2016): 96.

2. Dharmawan, Rafi, Heru Susilo, and Edlyn Khurotul Aini. Analisis Efisiensi Rekrutmen Karyawan Melalui Media Online Dan Media Konvensional (Studi Tentang Efisiensi Waktu dan Tenaga dari Pt. Jasa Marga (Persero) Tbk). Jurnal Administrasi Bisnis 64.1 (2018): 161-170.

3. Kumaladewi, Arishinta. Efektivitas Rekrutmen Dan Seleksi Dalam Memenuhi Kebutuhan Tenaga Perawat Di Rsia Muslimat Jomba. Parsimonia-Jurnal Ekonomi dan Bisnis 5.1 (2018): 29-40.

4. Larasati, Sri. Manajemen Sumber Daya Manusia. Deepublish, 2018.

5. Mallik, Arvind and Arpita Ptel Social Posting in Covid-19 Recruiting Era-Milestone Hr Strategy Augmenting Social Media Recruitment. Dogo Rangsang Research Journal Vol10 Issue-06 No. 2 June 2020

6. Martono, Nanang. Metode penelitian kuantitatif: Analisis Isi dan Analisis Data Sekunder (sampel halaman gratis). Raja Grafindo Persada, 2010.

7. Nanda, Kukuh Dwi, and Arik Prasetya. Efektifitas Penerapan Metode Rekrutmen Online (E-Recruitment) (Studi Pada PT Industri Kereta Api (INKA)-Jawa Timur). Jurnal Administrasi Bisnis 53.1 (2017): 96-104.

8. Supriyadi. Community of Practitioners: Solusi Alternatif Berbagi Pengetahuan antar Pustakawan. Lentera Pustaka: Jurnal Kajian Ilmu Perpustakaan, Informasi Dan Kearsipan 2.2 (2016): 83-93.

9. https://vt.tiktok.com/ZSXX62Vf/

10. https://www.estehindonesia.com/ 
11. https://www.facebook.com/esteh.indonesia/posts/lowongan-crew-kebun-es-tehsyaratnya-laki-laki-

12. perempuan-usia-19-sd-25-tahun-lul/1025383057848483/

13. https://www.madiunpos.com/masih-dibuka-es-teh-indonesia-rekrut-karyawan-lewattiktok-1051417 